\title{
Differential Testosterone Biosynthesis Relates to Decoupling of Reproductive Pattern in Peromyscus Syntopic Species (Rodentia: Muridae)
}

\author{
Arturo Salame-Méndez ${ }^{1 *}$, Alondra Castro-Campillo ${ }^{2}$, Ivan M. De la Cruz-Argüello ${ }^{3}$, Noé \\ González-Ruiz ${ }^{2}$, Jorge Haro-Castellanos ${ }^{1}$, Enrique Canchola-Martínez ${ }^{1}$, and José Ramírez- \\ Pulido $^{2}$ \\ ${ }^{1}$ Departamento de Biología de la Reproducción. División de Ciencias Biológicas y de la Salud (DCBS). \\ Universidad Autónoma Metropolitana, Unidad Iztapalapa (UAM-I). Iztapalapa CP 09340. CDMX. México. \\ ${ }^{2}$ Departamento de Biología. División de Ciencias Biológicas y de la Salud (DCBS). Universidad \\ AutónomaMetropolitana, Unidad Iztapalapa (UAM-I). Iztapalapa CP 09340. CDMX. México \\ ${ }^{3}$ Maestría en Biología División de Ciencias Biológicas y de la Salud (DCBS). Universidad \\ AutónomaMetropolitana, Unidad Iztapalapa (UAM-I). Iztapalapa CP 09340. CDMX. México
}

Corresponding Author: Arturo Salame-Méndez, Departamento de Biología de la Reproducción División de Ciencias Biológicas y de la Salud (DCBS). Universidad Autónoma Metropolitana, UnidadIztapalapa (UAM-I). Iztapalapa CP 09340. CDMX. México.

\begin{abstract}
Syntopic, congeneric species often deploy ecological strategies to avoid interspecific competition for any resource. Here we explore if the monthly and seasonal biosynthesis of sexual steroids involved in the $\triangle 4$ pathway, is one of such strategies for syntopic Peromyscus melanotis and Peromyscus difficiliss felipensis, since a differential pattern could affect, in turn, the temporality of their respective annual reproduction patterns. We found, indeed, an ecophysiological relationship between these two Peromyscus inhabiting at a midlatitude, temperate forest, since each had a monthly and seasonal species-specific pattern for sexual steroid production. We discuss how such differences are likely to account for the interspecific temporal decoupling of their respective reproductive patterns.
\end{abstract}

Keywords: Rodents, Peromyscus, testes, androgens, testosterone, temperate forest.

\section{INTRODUCTION}

Syntopic populations of rodents display strategies that allow them to avoid interspecific competition for any resource that could negatively affect their reproduction [1-3]. Among such strategies behavior patterns affected by steroid hormones, such as testosterone, may also be included. Since it regulates stages of spermatogenesis [4, 5], body growth [6, 7, 8], and sexual mating behavior [9, 10], testosterone is considered as one of the main androgens in males. In fact, testosterone can act as a pheromone or it can promote its synthesis [11-13], thus acting as an intra or interspecific signal, which in turn promotes distinctive territorial and breeding behaviors.

Syntopic, congeneric species are ideal models to document the relationship between production of androgens and the shifts on their respective reproductive patterns. Therefore, here we use syntopic populations of Peromyscus melanotis and $\mathrm{P}$. difficilis felipensis, inhabiting the midlatitude, temperate forests at the western suburbs of Mexico City. The former, the Black-eared deermouse, is a smallsized [14], cursorial, monotypic, and quasi-endemic species from Mexico [15-17]; dwelling in the ground of the alpine zone (> $4300 \mathrm{~m}$ ) [18], within the mentioned forested areas [19]. The latter belongs to a subspecies of the Mexican Rock deermouse, whose distribution extensively overlaps with the former species at the rural areas of Mexico City (e.g., Ajusco, Contreras) and of those nearby in the State of Mexico [20, 21]; this semiarboreal deermouse is medium-sized within Peromyscus [14].

Both species reproduce throughout the year in the study area but display particular reproductive patterns: Peromyscus difficilis felipensis has its greatest peak during spring [22] while P. melanotis has it during the summer [23]. Therefore, we wonder whether production of androgens in sexually mature males of these two species, is in accordance or not with the temporal interspecific differences 
in their reproductive pattern. In order to address this question, we describe how the testes of adult individuals of each species, carry out monthly as well as seasonal androgen production. Then we discuss both intra and interspecific variations in the biosynthesis of testosterone and its intermediary steroids in the light of possible deployed strategies to coexist in the same habitat.

\section{MATERIALS AND MeTHODS}

\subsection{Study Area}

Parque Nacional Desierto de los Leones (PNDL; Desert of Lions National Park), which is part of the Sierra de las Cruces (The Crosses Mountain Range), a continuation of Sierra del Ajusco (Ajusco Mountain Range), located east of Mexico Valley. Its climate is temperate sub-humid (C (w2) (w') (b') ig; [24]) with highest temperatures recorded in April-July (mean \pm standard deviation, $12.6 \pm 6^{\circ} \mathrm{C}$ ) and lowest temperatures in December-February $\left(8.1 \pm 2^{\circ} \mathrm{C}\right)$. The rainy season encompasses May-August $(235 \pm 30 \mathrm{~mm})$ and the dry season, December-February $(12 \pm 4 \mathrm{~mm})$. Sampling sites are located at $19^{\circ} 18^{\prime} 17^{\prime \prime} \mathrm{N}, 9^{\circ} 19^{\prime} 14^{\prime \prime} \mathrm{W}$, at $19 \mathrm{~km}$ from the park entrance (Alcaldía Álvaro Obregón), within 2180$3200 \mathrm{~m}$ of elevation. The arboreal stratum of this temperate forest harbors stocks of pine-oyamel (Pinus-Abies) and pine-oak (Pinus-Quercus). The understory includes several shrubs, especially Senecio sp. and Salix sp., together with herbaceous strata and scarce, scattered grasses. The ground stratum holds a variety of fungi, mosses and lichens.

\subsection{Rodent Capture and Preparation}

We trapped and selected male adult mice, using standard species-specific, pelage patterns [25], every month along a year, using Sherman live-traps $(8 \times 9 \times 23 \mathrm{~cm}$, Tallahassee, Fl.), baited with vanillaaromatized oat flakes. The same day of capture, we transferred mice to our laboratory facilities and killed by cervical dislocation. Each male was recorded its conventional external measurements and weight and prepared as skull and skeleton [26] to be housed at UAMI mammal collection. All animal manipulations followed international standards [27] and were approved by the Ethic Commission at DCBS, UAM-I.

\subsection{Evaluation of Testosterone Biosynthesis}

We removed the right testicle from each mouse and detached its tunica albuginea. Then introduced gonadal tissue into an Eppendorf tube, containing a Krebs-Ringer buffer solution with glucose (KRBG, pH 7) without metabolic cofactors. Each tube was added 10,000 cpm of tritiated cholesterol $\left(1,2-{ }^{3} \mathrm{H}\right.$ specific activity $47.7 \mathrm{Ci} / \mathrm{mmol} ; \mathrm{C}_{27}{ }^{3} \mathrm{H}$; New England Nuclear, Boston, MA). Experimental tubes (with tissue) and control tubes (without tissue) were incubated at $36^{\circ} \mathrm{C}$ for an hour. Metabolic reactions were stopped by freezing, and tubes were stored at $-70^{\circ} \mathrm{C}$ until analyses.

Procedures for homogenization, protein content determination, total steroids extraction, and efficiency determination, as well as those used for separation of each of sex steroids followed Salame-Méndez et al. [22], as described below.

\subsection{Homogenization of Tissues}

Gonadal tissues within experimental tubes were thawed and homogenized by sonication. Two aliquots were taken from each homogenate: one to evaluate biotransformation of precursor (tritiated cholesterol $\left[\mathrm{C}_{27}{ }^{3} \mathrm{H}\right]$ ) of each sex steroid and the other to determine protein concentration [28].

\subsection{Extraction of Total Steroids}

Total steroids were extracted from the aliquots of each homogenate by duplicate with diethyl ether. Average of total extraction efficiency was $97.4 \pm 0.6 \%$. Results of each of the biotransformation assessment was corrected based on percentage of recovery.

\subsection{Separation and Evaluation of Sexual Steroid Production}

Each tube containing its corresponding total steroid extract, as well as each control tube, was added a solution of diethyl ether: methanol $(2: 1, \mathrm{v} / \mathrm{v})$ and then transferred into glass chromatoplates $(20 \times 20$ $\mathrm{cm}$ ), covered with silica gel and UV radiation indicator (Merck). Fractions in the extracts over the chromatoplates, containing sexual steroids (pregnenolone, P5; progesterone, P4, 17 $\alpha$-hydroxyprogesterone, 17P4; androstenedione, A; and testosterone, T) were separated by TLC, using the 
Differential Testosterone Biosynthesis Relates to Decoupling of Reproductive Pattern in Peromyscus Syntopic Species (Rodentia: Muridae)

following chromatographic systems as mobile phases: (i) benzene; (ii) benzene:ethyl acetate (7:3, $\mathrm{v} / \mathrm{v})$, and (iii) benzene: methanol (95:5, v/v).

The zone corresponding to each reference steroid applied into chromatoplates was visualized with a UV lamp (254 and $366 \mathrm{~nm}$ ) and Oërtel's reagent (sulfuric acid:ethanol, 2:1, v/v). The area of the steroid to be scored was then scraped; such area coincides with the relative separation distance (Rf) of each reference steroid. The steroid adsorbed to the silica was then separated with diethyl ether:methanol solution $(1: 1, \mathrm{v} / \mathrm{v})$; the elusion was collected in glass vials.

Instagel (Packard) was added to each vial, and the radioactive metabolite was quantified in a liquid scintillation spectrophotometer (Beckman, LS-7000) with a maximum tritium efficiency of $54 \%$.

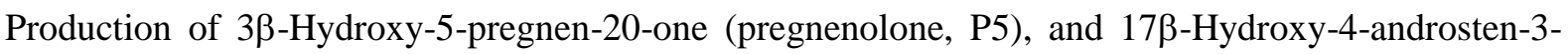
one (T), as well as its intermediaries of the $\Delta 4$ metabolic pathway: 4-Pregnene-3,20-dione (P4); 17 $\alpha$ Hydroxy-4-pregnene-3,20-dione (17P4); 4-Androstene-3,17-dione (A), were estimated from assessing biotransformation percentage of precursor $\left(\mathrm{C}_{27}{ }^{3} \mathrm{H}\right)$ into each steroid, per $100 \mathrm{mg}$ of gonadal protein per hour of incubation.

Statistical Analyses. After normality and homoscedasticity data tests, we ran analyses of variance (ANOVA), followed by Tukey's multiple comparison tests, in order to assess the monthly and seasonal concentration patterns for sex steroids, both within and between the syntopic, congeneric species. These quantitative analyses were performed with GraphPrisma routines [29] at a 90\% confidence level $(\alpha \leq 0.05)$.

\section{RESUltS}

Testes of adult males of both species biotransformed cholesterol into pregnenolone (P5), as well as into each one of the intermediary steroids in the $\Delta 4$ pathway (progesterone, P4; 17hydroxyprogesterone, 17P4, and androstenedione, A) for the synthesis of testosterone (T). However, since the metabolite 17P4 was above the lower limit of detection of radioactivity in all cases, its production was omitted in further descriptions of the synthesis profile of $\mathrm{T}$.

Production of sexual steroids (Fig. 1) mostly followed a statistically significant order in Peromyscus melanotis: $\mathrm{P} 5>\mathrm{T}>\mathrm{A} \approx \mathrm{P} 4(\mathrm{~F}=63.89, \mathrm{gl} 3,12,15, \mathrm{P}<0.0001)$; i.e., there was no significant difference between $\mathrm{P} 4$ and $\mathrm{A}$, though the former tended to be higher. From least to most produced steroid hormones in this species, the inter-monthly production profile of $\mathrm{P} 4, \mathrm{~A}$, and $\mathrm{T}$ followed a monomodal pattern, whose increase started from February until its maximum in August, to begin its descent from September on (Fig. 2A). In this species, seasonal profile for the biosynthesis of these three steroids (Fig. 2B) increased from the spring (March-May) until reaching its maximum during the summer (June-August); then descended from the autumn (September-November), to attain its minimal production during the winter (December-February).

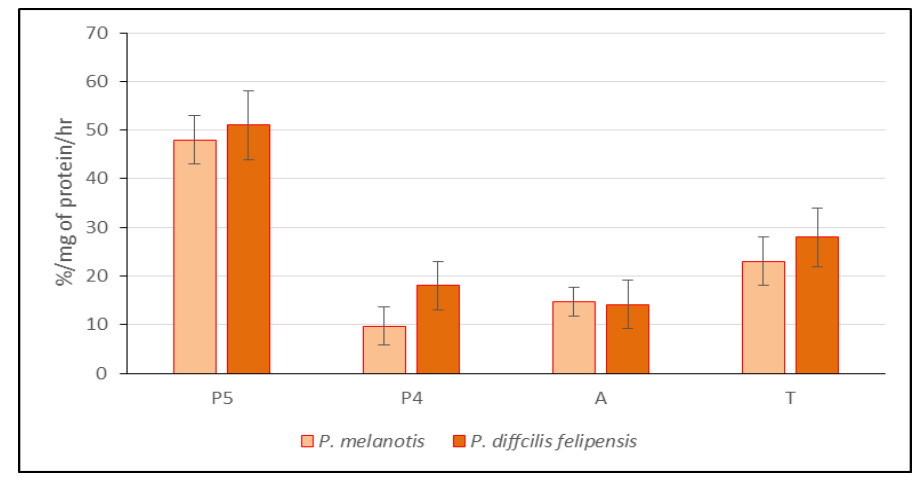

Figure1. Production of pregnenolone (P5), progesterone (P4), androstenedione (A), and testosterone (T) by the testicles of syntopic adult mice of Peromyscus melanotis and P. difficilis felipensis, at the same temperate forest. Synthesis of each steroid corresponds to biotransformation percentage of cholesterol per milligram of gonadal protein for one hour. Bars depict mean values and vertical lines \pm standard deviation of the former.

Peromyscus difficilis felipensis shared the previously described pattern for the biosynthesis of sexual steroids in the $\Delta 4$ pathway (Fig. 1), but with a slight order change between the last two sexual steroids: $\mathrm{P} 5>\mathrm{T}>\mathrm{P} 4 \approx \mathrm{A}(\mathrm{F}=86.46, \mathrm{gl} 3,16,19, \mathrm{P}<0.0001)$. However, in this species, from least to 
most produced, the inter-monthly profile of the biosynthesis of $\mathrm{A}, \mathrm{P} 4$, and $\mathrm{T}$ followed a bimodal pattern (Fig. 2C). One increase starts from October, reaching a first maximum in May that decreases by July; then another increase stops at a second maximum by August to attain its minimum by September, from where the pattern goes on. The seasonal profile for the biosynthesis of A, P4, and T in this species reaches a maximum in the spring that smoothly decreases towards the summer, from where it drastically descends until its lowest values in the autumn, but then towards the winter, it increases again until its spring peak (Fig. 2D).
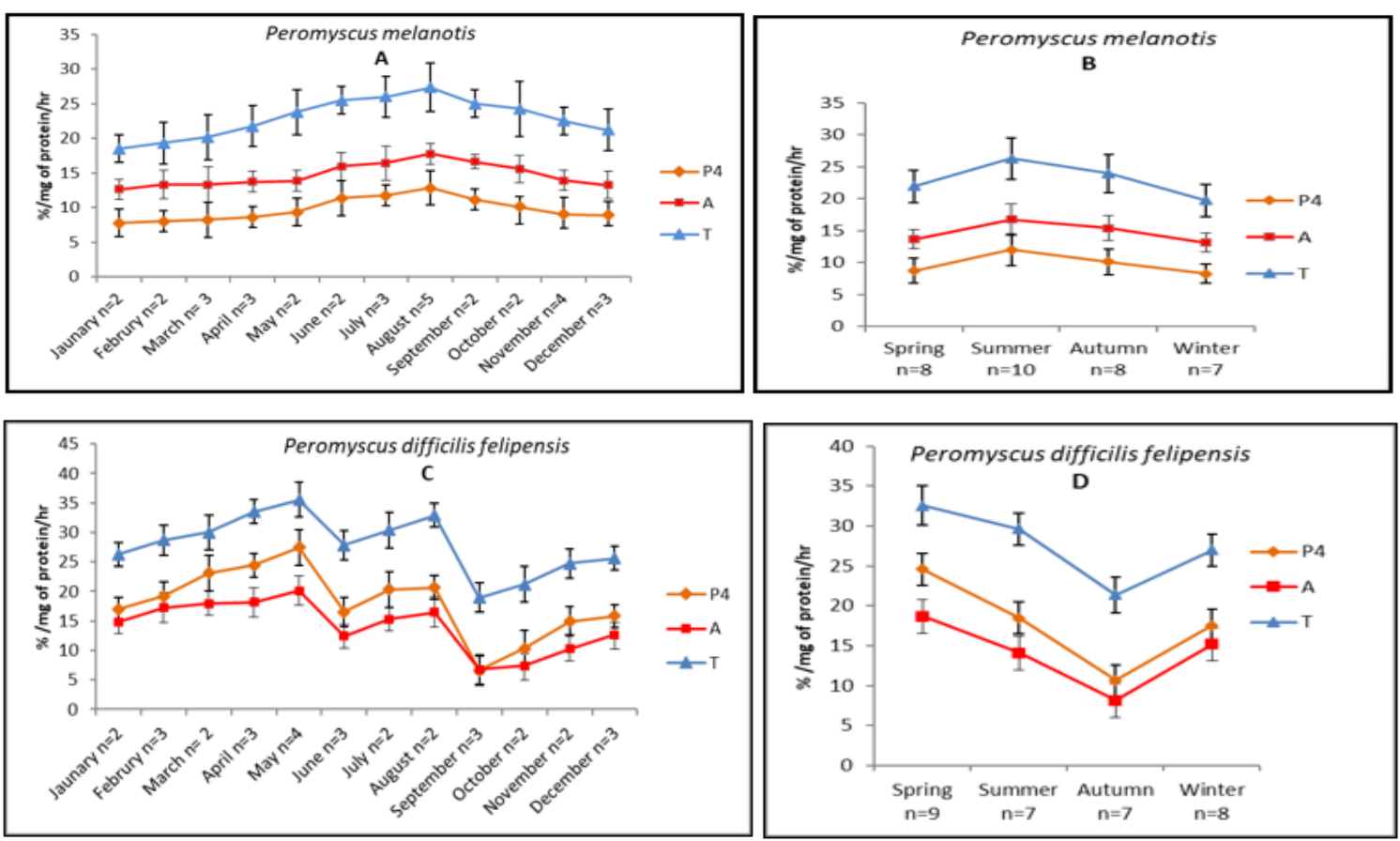

Figure2. Monthly (left) and seasonal (right) production profiles for progesterone $\left(P_{4}\right)$, androstenedione $(A)$, and testosterone $(T)$ in the testicles of adult mice of two Peromyscus species, occurring at the same temperate forest. Synthesis of each steroid corresponds to biotransformation percentage of cholesterol, per milligram of gonadal protein, for one hour; vertical lines depict one standard deviation around the means; $n=$ indicates number of analyzed mice in each month.

In overall, synthesis of $\mathrm{T}$ and its $\Delta 4$ intermediaries ( $\mathrm{P} 4$ and $\mathrm{A}$ ) were not significantly different $(\mathrm{P}>$ 0.05 ) between the two Peromyscus, especially in the production of $\mathrm{A}$, but there was a tendency in $\mathrm{P}$. d. felipensis to surpass P. melanotis in the production of P4 and T (Fig. 1). As noted before, production of $\mathrm{T}$ and $\mathrm{P} 4$ tended to be higher in $\mathrm{P}$. d. felipensis, while $\mathrm{T}$ and $\mathrm{A}$ seemed to be higher in $\mathrm{P}$. melanotis on monthly and seasonal basis, respectively (Fig. 2). The monthly synthesis profile of P4, A, and T, highlights the two evident peaks (May and August, respectively; Fig. 2C) in Peromyscus d. felipensis, whereas P. melanotis only presented one peak (August, Fig. 2A). Interspecific differences remain conspicuous during seasons of the year, since for $\mathrm{P}$. difficilis felipensis, the highest biosynthesis of the three steroids occurred during the spring (Fig. 2D), whereas it was highest during the summer for P. melanotis (Fig. 2B).

\section{DISCUSSION}

Androgens such as testosterone (T) are biosynthesized by the interstitial tissue of the testes through two alternative metabolic pathways: the $\Delta 4$ pathway and the $\Delta 5$ pathway. The name of each pathway depends on the intervening intermediary steroids for the synthesis of $\mathrm{T}$ [30], and depending on the species, one path predominates over the other; e.g., in laboratory rodents such as the albino mouse (Mus musculus) and the white rat (Rattus norvegicus), the $\Delta 4$ pathway predominates [31, 32]. Results here confirm our previous findings (Peromyscus melanotis, [22]; P. difficilis, [23]) for the production of androgens in adult male mice: (i) in both Peromyscus, $\mathrm{T}$ biosynthesis is carried out via the $\Delta 4$ pathway, and (ii) $\mathrm{T}$ production has a distinctive interspecific profile in either monthly or seasonal basis. 

Syntopic Species (Rodentia: Muridae)

The temporal tendency of a greater production of $\mathrm{T}$ and its intermediary steroids in P. d. felipensis with respect to P. melanotis, may have consequences on various processes of its biology, such as its searching behavior for foraging areas or mating territories on suitable habitats, as well as on its sexual behavior. In fact, spatiotemporal marking of species-specific territories for foraging and breeding, can be achieved through the excretion of substances that can act as pheromones in urine and faeces [33]. Pheromones act as stimulating signals for both intra and interspecific distinctive behaviors $[34,35]$ that can be regulated by $\mathrm{T}[13,36]$; e.g., they are magnified, becoming thus distinctive, with the concomitant concentration increase of the androgen [37]. Such acting as pheromones by T and some of its metabolites has been reported elsewhere [e.g., 12, 38-40].

Therefore, our results support a species-specific pattern of testicular biosynthesis of testosterone (T) and androstenedione (A), T in adult males of two syntopic species of Peromyscus, sharing habitat and resources in this midlatitude, temperate forest. The fact that both androgens tend to be more produced in P. d. felipensis throughout the year, adds up to a couple of evidences gathered from our previous and current studies. First, the medium-sized P. d. felipensis behaves as a permanent dweller, whereas the small-sized P. melanotis is rather a fluctuating inhabitant in the area [25]. Second, as for the use of space, the former is territorial and while the latter is rather opportunistic, they rarely overlap, especially during mating season [41]. Therefore, together these data support that upon being secreted into the bloodstream and subsequently excreted, such androgens could act as regulatory substances, such as pheromones, in the species-specific marking of temporal territories for foraging and for breeding areas, according to shifts in both climate conditions and availability of resources, such as food and shelter.

On the other hand, it is known that sexual behavior is regulated by steroid hormones such as progesterone ( $\mathrm{P} 4)$ and $\mathrm{T}$ [10], which stimulate or delay reproduction [36], thus affecting the deployment of diverse mating strategies [42]. As has been documented in other species of the Genus Peromyscus [43, 44], it is highly likely that during their respective breeding season, the testes of P. d. felipensis and P. melanotis, produce these steroid hormones and secrete them into bloodstream from where they reach the hypothalamus and pituitary. Thence, these sexual steroids can act as modulators of agonistic displays towards other males, in order to compete for estrous females.

Our data allow us to propose that differential capacities for testosterone biosynthesis are related to spatiotemporal marking of mating territories, as well as to verify that the production of sexual steroids can explain the seasonal decoupling of the reproductive peaks in P. d. felipensis (spring) and P. melanotis (summer) at PNDL. This pattern of differential production of sexual steroids throughout the year, contributes to document our knowledge of the sexual behavior and reproductive patterns used by syntopic, congeneric Peromyscus dwelling at midlatitude, temperate forests.

\section{ACKNOWLEDGMENT}

Our appreciation for his invaluable fieldwork and for his assistance in cabinetwork to the late Juan Patiño Rodríguez, collector and taxidermist technician at UAMI Mammal Collection. We also thank the several undergraduate and graduate students that participated during fieldwork. This study was partially supported by the Division of Biological and Health Sciences in UAMI (DCBS-144.03.07 to A.S.M., and DCBS-143.02.46 to ACC), by the National Council of Science and Technology (CONACyT-1253-9203 y 400200-5R29117N to JRP), and by the Public Education Secretariat (SEP 94-01-00-002-247 to JRP).

\section{REFERENCES}

[1] Giant P. R., Interspecific competition among rodents. Annu. Rev. Ecol. Evol. Syst. 3: 79-106. (1972).

[2] Anderson, P. K., Dispersal in Rodents: A Resident Fitness Hypothesis. Provo, UT. 2., Amer. Soc. Mamm., Spec. Publ. 9:vii+141. (1989).

[3] Kaufman D. W. and G. A. Kaufman, Population Biology. In Advances in the Study of Peromyscus (Rodentia). G. Kirkland Jr. and J. Layne, eds. Texas Tech University Press, Lubbock TX, pp. 233-271. (1989).

[4] Komori, S., H. Kasumi, K. Sakata, and K. Koyama, The role of androgens in spermatogenesis. Soc. Reprod. Fertil. (Suppl.), 63: 25-30. (2007).

[5] Walker W. H., Testosterone signaling and the regulation of spermatogenesis. Spermatogenesis 1(2): 116120. (2011). 
[6] Keenan B. S., G. E. Richards, S. W. Ponder, J. S. Dallas, M. Nagamani, and E. R. Smith, Androgenstimulated pubertal growth: the effects of testosterone and dihydrotestosterone on growth hormone and insulin-like growth factor-I in the treatment of short stature and delayed puberty. J. Clin. Endocrinol. Metab. 76(4): 996-1001. (1993).

[7] Sheffield-Moore M., Androgens and control of skeletal muscle protein synthesis. Ann. Med. 32(3): 181186. (2000).

[8] Venken K., S. Movérare-Skrtic, J. J. Kopchik, K. T. Coschingano, C. Ohlsson, S. Boonen, R. Bouillon, and D. Vanderschueren, Impact androgens, growth hormone, and IGF-I on bone and muscle in male mice during puberty. J. Bone Miner. Res. 22(1): 72-82. (2007).

[9] Baum M. J., Differentiation of coital behavior in mammals: A comparative analysis. Neurosci. Biobehav. Rev., 3(4):265-284. (1979).

[10] Nelson, R. J., An Introduction to Behavioral Endocrinology. $4^{\text {th }}$ Edition. Sinauer Associated Inc., Sunderland, MA. (2011).

[11] Lombardi J. R., J. G. Vandenbergh, and J. M. Whitsett, Androgen control of the sexual maturation pheromone in house mouse urine. Biol. Reprod. 15(2): 179-186. (1976).

[12] Clemens, L. and Pomerantz, S., Testosterone acts as a prohormone to stimulate male copulatory behavior in male Deer Mice (Peromyscusmaniculatusbairdii). J. Comp. Physiol. Psychol. B4a 96: 114-112. (1982).

[13] Kakuma Y., T. Ichimaru, T. Yonezawa, Y. Momozawa, C. Hashizume, E. Iwata, T. Kikusui, Y. Takeuchi, S. Ohkura, H. Okamura, and Y. Mori, Androgen induces production of male effect pheromone in female goats. J. Reprod. Develop. 53(4): 829-834. (2007).

[14] Hall, E. R., The Mammals of North America. Vol. 2. John Wiley \& Sons. $2^{\text {nd }}$ Edition. NY, pp. 684-704. (1981).

[15] Bowers, J. H., R. J. Baker, and M. H. Smith, Chromosomal, electrophoretic, and breeding studies of selected populations of Deer Mice (Peromyscusmaniculatus) and Black-eared Mice (P. melanotis). Evolution, 27(3):378-386. (1973).

[16] Bowers, J. H., Genetic compatibility of Peromyscusmaniculatus and Peromyscusmelanotis, as indicated by breeding studies and morphometrics. J. Mamm. 55(4):720-737. (1974).

[17] Martínez-Coronel M., J. Ramírez-Pulido, and T. Álvarez, Variación intrapoblacional e interpoblacional de Peromyscusmelanotis (Rodentia: Muridae) en el Eje Volcánico Transverso, México. Acta Zool. Mex. (n. s.) 47: 1-51. (1991).

[18] Villa, B. R. and F. A. Cervantes, Los Mamíferos de México. Instituto de Biología, UNAM y Grupo Editorial Iberoamérica. México D. F. (2003).

[19] Castro-Campillo, A., Martínez-Coronel, M., Aguilera, U. and Ramírez-Pulido, J.Peromyscusmelanotis (J. A. Allen and Chapman, 1897). In Ceballos G., editor. Mammals of Mexico, Johns Hopkins University Press. Baltimore, MD, USA, pp. 378-379. (2014).

[20] Hoffmeister, D. F. and L. de la Torre, Geographic variation in the mouse Peromyscusdifficilis. J. Mamm. 42: 1-13. (1961).

[21] Chavez-T., J. C. and Ceballos, G., Peromyscusdifficilis. (J. A. Allen, 1891). Southern Rock Deermouse. In Ceballos G., editor. Mammals of Mexico, Johns Hopkins University Press. Baltimore, MD, USA, pp. 351352. (2014).

[22] Salame-Méndez, A., A. Castro-Campillo, E. Mendieta-Márquez, I. H. Salgado-Ugarte, J. Herrera-Muñoz, and J. Ramírez-Pulido, Evaluaciónestacional de la producción de esteroidessexualesentestículos del ratón de orejasoscuras (Peromyscusmelanotis Allen y Chapman, 1897) de diferentesclases de edad. Acta. Zool. Mex. (n. s.) 20(2): 103-114. (2004).

[23] Salame-Méndez, A., E. Mendieta-Márquez, J. Herrera-Muñoz, A. Castro-Campillo, and J. RamírezPulido, Evaluación de la producción de hormonasesteroidesentestículos y ovarios del ratón de las rocas (Peromyscusdifficilisfelipensis). Rev. Soc. Mex. Hist. Nat. (3ª́poca) 2(1): 200-206. (2005).

[24] García, E., Modificaciones al Sistema de Clasificación Climática de Köpen (para adaptarlo a la República Mexicana). $5^{\text {a } e d i c i o ́ n . ~ I n s t i t u t o ~ d e ~ G e o g r a f i ́ a-U N A M . ~ M e ́ x i c o, ~(2004) . ~}$

[25] Castro-Campillo, A., A. Salame-Méndez, J. Vergara-Huerta, A. Castillo y J. Ramírez-Pulido, Fluctuaciones de micromamíferos terrestres en bosques templados aledaños a la Ciudad de México, Distrito Federal. In Lorenzo, C., Espinosa, E. y Ortega, J., Eds. Avances en el Estudio de los Mamíferos de México -II-. Asociación Mexicana de Mastozoología, A. C. México, pp 391-410. (2008).

[26] Ramírez-Pulido, J., I. Lira, S. Gaona, C. Müdespacher, and A. Castro, Manejo y Mantenimiento de Colecciones Mastozoológicas. Universidad Autónoma Metropolitana, Unidad Iztapalapa. México, (1989).

[27] NRC. Guide for the Care and Use of Laboratory Animals. National Research Council, National Academies, National Academy of Sciences. $8^{\text {th }}$ Edition. The National Academies Press. Washington, D. C. (2011). 
Differential Testosterone Biosynthesis Relates to Decoupling of Reproductive Pattern in Peromyscus Syntopic Species (Rodentia: Muridae)

[28] Groves, W. E., Davis, F. C., Jr., and Sells, B. H., Spectrophotometric determination of microgram quantities of protein without nucleic acid interference. Anal. Biochem. 22(2): 195-210. (1968).

[29] Motulsky, H. J., Analyzing Data with GraphPad Prism.GraphPad Software Inc., San Diego, CA, USA, www.graphpad.com. (1999).

[30] Norman, A. W. and G. Litwack, Hormones. $2^{\text {nd }}$ edition. Academic Press. San Diego, CA. (1997).

[31] Lipsett, M. B., Steroid Hormones. InReproductive Endocrinology: Physiology and Clinical Management. S. S. C. Yen and R. Jaffe, eds. W. B. Saunders Co. Philadelphia, PA, pp. 140-153. (1986).

[32] Henricks, D. L., Biochemistry and Physiology of the Gonadal Hormones, In Reproduction in Domestic Animals. Perry T. Cupps, ed., $4^{\text {th }}$ Edition. Academic Press, Inc. San Diego, CA, Chap. 3, pp. 81-118. (1991).

[33] Jemiolo B., D. J. Gubernick, C. Yoder, and M. Novotny, Chemical characterization of urinary volatile compounds of Peromyscuscalifornicus, a monogamous biparental rodent. J. Chem. Ecol. 20(10): 24892500. (1994).

[34] Johnston R. E., Chemical communication in rodents: From pheromones to individual recognition. J. Mamm. 84(4): 1141-1162. (2003).

[35] Brennan, P. A. and F. Zufall, Pheromonal communication in vertebrates. Nature 444(7117): 308-315. (2006)

[36] Drickmer L. C., Acceleration and Delayed of Reproduction in Rodents. In Jerry O. Wolff and Paul W. Sherman, eds. Rodent Societies: An Ecological and Evolutionary Perspective. University of Chicago Press. Chicago. IL. USA. Chapter 9, pp 106-113. (2007).

[37] Ferkin, M. H., Sorokin, E. S., Renfroe, M. W., and Johnston, R. E., Attractiveness of male odors to females varies directly with plasma testosterone concentration in meadow voles. Physiol. Behav. 55(2): 347-353. (1994).

[38] Norris, D. O., Vertebrate Endocrinology. $3^{\text {th }}$ edition. Academic Press. San Diego, CA. (1997).

[39] Bentley, P. J., Comparative Vertebrate Endocrinology. $3^{\text {th }}$ edition. Cambridge University Press. Cambridge, UK. (1998).

[40] Wilson, J. D., M. W. Leihy, G. Shaw, and M. B. Renfree, Androgen physiology: unsolved problems at the millennium. Mol. Cell. Endocrinol. 198: 1-5. (2002).

[41] De-La Cruz-Argüello, I. M., A. Castro-Campillo, A. Zavala-Hurtado, A. Salame-Méndez, and J. RamírezPulido, Differentiation pattern in the use of space by males and females of two species of small mammals (Peromyscusdifficilisand P. melanotis) in a temperate forest. Therya, 10(1): 3-10. (2019).

[42] Waterman, J.,Male Mating Strategies in Rodents. In Rodent Societies: An Ecological and Evolutionary Perspective. Jerry O. Wolff and Paul W. Sherman, eds. The University of Chicago Press, Chicago, IL. USA. Chapter 3, pp 27-41. (2007).

[43] Lidicker W. Z., Jr., The Role of Dispersal in the Demography of Small Mammals. In Small Mammals: Their Productivity and Population Dynamics, F. B. Golley, K. Petrusewics, and L. Ryszkowski, eds. IBP 5. Cambridge University Press. London, UK, Pp. 103-128. (1975).

Citation: Arturo Salame-Méndez., et.al., "Differential Testosterone Biosynthesis Relates to Decoupling of Reproductive Pattern in Peromyscus Syntopic Species (Rodentia: Muridae)", International Journal of Research Studies in Zoology, vol. 5, no. 2, p. 1-7, 2019. DOI: http://dx.doi.org/10.20431/2454-941X.0502001

Copyright: (c) 2019 Authors. This is an open-access article distributed under the terms of the Creative Commons Attribution License, which permits unrestricted use, distribution, and reproduction in any medium, provided the original author and source are credited. 